\title{
NÅR VERDENER ER AMULETTER \\ Shamanisme, ting og ontologi blandt duhaerne i Mongoliet
}

\author{
BENEDIKTE MØLLER KRISTENSEN
}

Jeg ved ikke, hvordan jeg nogensinde skal blive shaman, når min shamanlærer ikke forklarer mig noget som helst. Og mine slægtninge taler kun om de her 'dårlige ting'. De siger, at zobelskindet på min shamandragt er en 'dårlig ting', og at jeg i stedet skal fæstne en trehovedet slange til dragten. Jeg forstår ikke, hvad de egentlig taler om.

Med ovenstående ord beskrev den duhaske/mongolske kvinde Ojuna nogle af de frustrationer, som hun gennemlevede i sit forsøg på at blive oplært som shaman blandt duhaske rensdyrnomader i den nordmongolske tajga. Ojuna havde altid vidst, at hendes morfar var duha og shaman, men hun havde aldrig kendt ham. Selv var hun opvokset fjernt fra tajgaen i byen Darhan med sin mongolske far og duhaske mor, havde læst økonomi på universitetet i Ulaanbataar og var siden emigreret til Tyskland. I sommeren 2011 rejste hun tilbage til Mongoliet i håbet om at følge i sin morfars fodspor og blive initieret som shaman hos duhaerne $\mathrm{i}$ tajgaen. I denne artikel vil jeg forsøge at besvare Ojunas spørgsmål om, hvilken rolle ting egentlig spiller i initieringen af duhaske shamaner. Da jeg spurgte Ojunas moster om dette, forklarede hun:

Ojunas morfars ånder kan ikke genkende hende, fordi hendes shamandragt står i kontrast (hoorondoo harshildah) til dem. Zobelskind hører ikke til på hendes shamandragt. Det er en dårlig ting (тии yum), fordi det ikke passer sammen med (taarahgüi) shamanen Nazyns [Ojunas morfar] åndeamulet (eren). Først når shamandragten er lavet korrekt, vil ånderne (eren) genkende Ojuna [som slægtsmedlem]. Så falder de til ro og slår sig ned i hendes shamandragt.

Duhaerne praktiserer en form for lokal shamanisme, der er karakteristisk ved, at kosmologien er forankret i den lokale slægtskabsstruktur, konkrete amuletter og det omgivende landskab, de bebor (se Vitebsky 1995). Det duhaske begreb „dårlig ting" kan forstås i relation til deres shamanistiske kosmologi, hvor tingenes 
beskaffenhed varierer fra shamanslægt til shamanslægt, da den afgøres af slægtens særlige menneskelige historie og ikke-menneskelige natur, som er indlejret i dens åndeamuletter. Enhver duha tilhører en eller flere shamanslægt(er) (sin mors og fars), som har hver sine særlige åndeamuletter (eren), ${ }^{1}$ der har oprindelse i en specifik historisk shaman og hans/hendes særegne kraft (huch) og ånder, som går i arv fra shaman til shaman i slægten og kontinuerligt påvirker hele slægtens liv og skæbne.

Med udgangspunkt i Claude Lévi-Strauss' (1963) klassiske totemismeteori kan vi se duhaernes erenamuletter som repræsenterende duhaernes slægtskabsstruktur, hvor hver eren står for sin shamanslægts særegne ånder og kraft, og forskellene mellem dem markerer de sociale forskelle mellem slægterne. I totemismen er det ifølge Lévi-Strauss ikke artens egenart, men forskellene mellem arterne, der er vigtig. At naturen/verden kan opdeles - „detotaliseres“ - i arter og grupper betyder, at den kan anvendes til at repræsentere og konstruere sociale forskelle i menneskelige samfund. Ser vi på duhaernes begreb „,dårlig ting“ ud fra denne tolkning, er det således ikke den egentlige ting, der er vigtig (hvorvidt det er et zobelskind eller en trehovedet slange), snarere anvendes forskellene mellem tingene til at markere og forhandle de sociale grænser mellem shamanslægterne.

Begrænsningen i dette perspektiv er dog, at det tager udgangspunkt i en vestlig ontologi, ${ }^{2}$ som i modsætning til duhaernes shamanistiske ontologi beror på antagelsen om, at natur/ting/verden refererer til det almene og generelle, mens kultur/repræsentationer udgør det mere særegne og partikulære (se Viveiros de Castro 1998:470). De duhaske fænomener eren og ,dårlig ting“ kan ikke begribes alene gennem dette perspektiv, da deres betydning er forankret i duhaernes shamanistiske ontologi, hvor der ikke er et klart skel mellem natur og kultur.

Erenamuletterne repræsenterer ikke blot shamanslægten, snarere er de slægtens særlige ånder, kraft og egenart, hvad vi kan kalde slægtens særegne natur eller verden. ${ }^{3}$ Om en ting er dårlig eller ej, afhænger af den enkelte shamannovices erenamulet(ters) natur eller beskaffenhed. Duhaernes shamanistiske ontologi indebærer således en forestilling om, at der ikke findes en objektiv verden derude, snarere er der myriader af verdener, da hver slægt udgør sin særegne natur og verden med sine særegne regler for korrekt omgang med ting og væsener i verden. Fælles for duhaerne er, at de alle tolker deres særegne eren ud fra det, de kalder „naturloven“ (jam), som indeholder et princip om, at mennesket ideelt set skal leve i overensstemmelse med sin egenart (som menneske og som slægt) og undgå at intervenere med andre væsener og ting af en anden egenart. Eksempelvis har alle slægter nogle ting, der er dårlige for dem, fordi de udtrykker en uoverensstemmelse mellem slægtens erens iboende natur eller historie og tingens iboende natur eller historie. Hvad der er foranderligt er, hvilke ting der er dårlige for hvilke slægter. 
Skal vi forstå, hvad duhaernes begreber eren og „dårlig ting“ egentlig betyder, må vi, således som repræsentanter for den ontologiske vending i antropologien foreslår, forstå dem ud fra den ontologi, inden for hvilken begrebet giver mening (Henare et al. 2007). Dette spring fra kosmologi/verdenssyn til ontologi refererer til et skift fra at betragte lokale begreber som udtryk for forskellige kosmologier eller perspektiver på den samme verden til ,,i stedet at opfatte disse som skildringer af forskellige 'verdener' eller 'naturer'“' (op.cit.10).

I artiklen vil jeg følge Henare, Holbraad og Wastells forslag om at „tage informanternes ord for pålydende“ og begive mig på en rejse ind i de verdener, de ,dårlige ting“ måtte åbne op for. Dette vil inkludere en analyse af, hvordan duhaernes religiøse amuletter udgør et slags levende kort over slægters verdener, og hvordan de „dårlige ting“ synliggør de overordnede principper i duhaernes „naturlov“ og det særegne udtryk, den antager i den enkelte shamanslægt. Endelig vil jeg undersøge, hvilken rolle duhaernes opmærksomhed på rygter om erenamuletter og på, hvad Lars Højer kalder „fravær af viden“" om dem, spiller i konstruktionen og rekonstruktionen af duhaernes verdener (Højer 2009:585).

\section{Duhask shamanisme}

Duhaerne er et tuvinsk rensdyrnomadefolk, der lever i den nordlige mongolske provins Khövsgöl i kommunen Tsagaan Nuur. I Mongoliet er der kun godt 500 duhaer, hvoraf ca. 200 stadig praktiserer deres traditionelle levevis som rensdyrnomader og jægere i tajgaen (skoven) tæt på grænsen til Rusland (Sibirien).

Duhaernes shamanistiske tradition har i modsætning til andre shamanistiske traditioner i regionen kun været underlagt meget sporadiske antropologiske analyser (Wheeler 2000), hvorfor denne artikel udspringer af mine egne studier af duhaernes shamanisme (Kristensen 2004, 2007a, 2007b) perspektiveret med studier af shamanisme blandt andre oprindelige folk i regionen.

Nyere studier af shamanisme i Mongoliet og Sibirien kan inddeles i to overordnede tematikker. På den ene side finder vi studier af den revitalisering af shamanisme, som er opstået blandt flere af regionens oprindelige folk i kølvandet på de socialistiske staters sammenbrud. ${ }^{4}$ Disse studier undersøger, hvordan globalisering (Vitebsky 1995; Lindquist 2011), makropolitiske statslige ændringer (Humphrey 1999), etnisk identitetskrise (Shinamura 2004; Lindquist 2011) og social usikkerhed (Buyandelgerin 2007) former lokale shamanistiske traditioner. På den anden side har vi nyere studier med fokus på kosmologi og/eller ontologi, hvor klassiske teorier om animisme og totemisme og nyere teorier om perspektivisme anvendes til at belyse lokale shamanistiske kosmologier og/eller ontologier (Willerslev 2007; Pedersen 2001, 2007, 2011; Empson 2007, 2011). 
Flere af disse studier har påpeget, at shamanistiske ontologier blandt oprindelige folk i det nordlige Sibirien er domineret af en ,,animistisk form“ (Pedersen 2001; Willerslev 2007), hvor relationen mellem mennesker og ikke-mennesker (dyr og ånder) er baseret på ,,analogisk identifikation“, mens shamanistiske ontologier blandt oprindelige folk i Mongoliet og det sydlige Sibirien primært er domineret af en „totemisk form“, hvor mennesker og ikke-mennesker betragtes som hensat i „gensidigt uafhængige domæner“ (Pedersen 2001:418). Duhaerne synes at adskille sig fra de omkringliggende shamanistiske folk i Mongoliet og Sydsibirien, da duhaernes shamanistiske ontologi er domineret af en mere ,animistisk form “ og således minder mere om shamanisme blandt oprindelige folk i det nordlige Sibirien, hvor relationen mellem mennesker og ikke-mennesker bygger på analogisk identifikation, hvor en specifik slægts særegne natur betragtes som analog med et særligt dyrs eller en særegen ånds natur, som igen er formgivende for slægtens specifikke regelkodeks. Duhaernes shamanistiske ontologi har samtidig islæt af totemisme, da det menneskelige samfund betragtes som opdelt $\mathrm{i}$,gensidigt uafhængige domæner", hvor hver slægt tilhører sin slægts domæne, som er analogt med slægtens eren, som adskiller sig fra andre slægters erenamuletters domæner. Denne artikel falder således ind under den sidste kategori af studier, da den ønsker at undersøge, hvordan duhaernes erenamuletter synliggør deres særegne animistiske ontologi og dens totemistiske islæt.

\section{Viden og fravær af viden om verden}

Flere antropologer har undersøgt betydningen af ting i Mongoliet og Sydsibirien (Humphrey 2007; Empson 2007; Pedersen 2007, 2011; Højer 2009), hvor særligt mongolerne og tuvinernes religiøse amuletter har været genstand for analyse (Humphrey 1971; Vainshtein 1978; Purev \& Purvee 2005; Humphrey 1996; Pedersen 2007; Charleux 2010; Kristensen 2007a). Amuletter (ongod) er blevet beskrevet som en form, der udgør ,en generalisering af de menneskelige vilkår“ (Humphrey 1996:192), ,animerede portrætter“(Charleux 2010:7) og „talismaner for tænkning“ (Pedersen 2007:153). Også opfattelsen af personlig ejendom i Mongoliet er blevet underkastet flere antropologiske analyser (Humphrey 2002; Empson 2007). Rebecca Empson skriver, at personlig ejendom i buriyathushold i Mongoliet virker som et slags indeks over menneskelige relationer. De er de tegn, hvorigennem fortidige og fraværende slægtsrelationer manifesterer sig for og begribes af nutidige slægtsmedlemmer (2007:135).

Duhaernes erenamuletter synes at materialisere slægtens særlige natur, historie og regelkodeks. En erenamulet består typisk af et bundt af stofstrimler, lædersnore og kropsdele (fjer, klør, negle) fra et eller flere vilde dyr. Kropsdelene og 
stofstrimlerne vidner om slægtens særlige natur (dens oprindelse i en eller flere dyreånder og andre ikke-menneskelige ånder og kræfter) og historie (nutidige og fortidige shamaners liv og handlinger). Hver shamanslægt har sine erenamuletter, der alle har oprindelse i den særlige kraft og de særegne ånder, der gav liv og kraft til slægtens første shaman og hans/hendes erenamulet. Hver gang en shaman dør, fæstner hans slægtninge hans erenamulet og øvrige shamanudstyr til et særligt offertræ i naturen, hvorfra de kontinuerligt påvirker slægtens liv og skæbne. Før eller siden vil et nyt medlem af slægten få en såkaldt shamansygdom (böögiin övchin), hvilket indikerer, at ånderne har udvalgt denne person som potentiel ny shaman i slægten. Udfordringen er dog at konstruere novicens eren og øvrige shamanudstyr således, at ånderne genkender novicen som slægtsmedlem. Lykkes det, falder ånderne til ro, slår sig ned i novicens eren og øvrige shamanudstyr og gør ham eller hende til shaman. Lykkes det ikke, ophidses ånderne, hvilket potentielt kan føre til novicens sindssyge eller død.

Ifølge Morten Axel Pedersen (2007) er den shamanistiske viden blandt darhadfolket i Mongoliet forankret i religiøse objekter, hvis „design udløser folks momentvise begrebsliggørelse af sociale relationer, som ellers er uforudsigelige og ukendte" (op.cit.141). Blandt duhaerne synes erenamuletter at materialisere shamanslægtens særlige natur og historie, hvor „dårlige ting“ både kan være et indeks på et misforhold mellem naturer (erenobjektets egenart versus tingens egenart) eller et udtryk for en uoverensstemmelse mellem fortidige og nutidige menneskeliv. Fælles er, at begge uoverensstemmelser synliggør duhaernes fælles normer og værdier for korrekt omgang med mennesker og ikke-mennesker (dyr og ånder), hvad duhaerne betegner under begrebet „,naturloven“ (se Kristensen 2007b). De „,dårlige ting“" synliggør naturlovens princip i form af ideen om, at hver art skal imitere sin egen art, hvor udfordringen for hver slægt er at imitere netop sin egen art (shamanslægt) gennem sit shamanudstyr og sine handlinger.

Det er min erfaring, at fænomenet ,dårlig ting“ er centralt i både de tuvinske og mongolske folks shamanistiske traditioner. Alligevel har der kun været begrænset fokus på det i den ellers vidtfavnende antropologiske debat om ting i regionen. En af de få, der har beskæftiget sig mere direkte med begrebet „dårlig ting“, er Lars Højer (2009). Han har bl.a. undersøgt, hvorfor mange mongolske familier i dag skaffer sig af med deres religiøse objekter. Højer skriver, at mange mongoler føler, at socialismens systematiske forsøg på at eliminere religionen har frarøvet dem viden om egne religiøse traditioner, et tab af viden, mange erfarer gennem egne religiøse objekter, hvis betydning de ofte ikke kender, hvorfor objekterne synliggør eget ,fravær af viden“ om det religiøse (op.cit.585). Når mongoler ofte skaffer sig af med religiøse objekter, skyldes det ifølge Højer ikke manglende tro, men netop troen på og frygten for de religiøse objekters potentielle kræfter. På den ene side ser Højer dette „fravær af viden“" som et biprodukt af socialismens 
strategiske forsøg på at eliminere den såkaldte overtro, som vakte det til live ideen om tilstedeværelsen af noget, der var så farligt, at staten måtte sætte alt ind på at destruere det - som den forsøgte at ødelægge (op.cit.579). Men vækkelsen tog form af en viden om et tab af viden, altså et „fravær af viden“"(op.cit.576). På den anden side anser Højer dette „fravær af viden“ som en iboende del af det religiøse, som giver religiøse objekter deres særlige effektivitet og kraft, da de indeholder „lag på lag af hemmeligholdelse“, som leder folks opmærksomhed hen mod „det fængslende uvisse“" (op.cit.585f.).

Højer gør i artiklen op med den ontologiske vending i antropologiske studier af kosmologier og praksisser i Mongoliet og indre Asien og påpeger, at visse magisk-religiøse praksisser kun kan forstås ved at inkludere ,fravær af viden“ $i$ vores studier. Blandt duhaerne betragtes shamannovicens manglende evne til at hidkalde ånderne og blive shaman som et slags indeks på tilstedeværelsen af en „,årlig ting“, der på en eller anden vis står i kontrast til slægtens eren. Det er ofte shamaner, der udpeger den specifikke ,dårlige ting“, dog mange gange uden yderligere forklaring, end at den står i kontrast til slægtens eren. Forekomsten af en „,dårlig ting“ synes at materialisere et „fravær af viden“ om erens sande natur eller verden, der ofte iværksætter refleksioner og rygter om den enkelte slægts oprindelse og historie.

Det er min foreløbige tese, at forståelsen af duhaernes eren ikke kan reduceres til det ontologiske, ej heller til „fravær af viden“. Snarere konstrueres og rekonstrueres deres beskaffenhed kontinuerligt i spændingsfeltet mellem „,viden“ og „fravær af viden“, hvilket blev særligt klart, da jeg under mit feltarbejde fulgte den duhaske/mongolske kvinde Ojunas forsøg på at blive shaman.

\section{Rejsen ind i shamanens verden}

I sommeren 2011 ankom Ojuna til tajgaen sammen med sin mor, lillebror og sin mongolske shamanlærer i håb om at blive udfriet af de psykiske forstyrrelser, der havde plaget hende i en årrække. I Ulaanbataar havde en shaman fortalt hende, at hun havde en shamansygdom. I årevis havde hun haft mærkelige oplevelser: Hun hørte stemmer, så lærkeskove, hørte sang og trommen, selv når hun stod $\mathrm{i}$ kø i supermarkedet i Frankfurt eller kørte i sin Mercedes på den tyske motorvej. Dette skyldtes ifølge flere shamaner, at hendes morfar Nazyn havde udvalgt hende til at blive den næste shaman i slægten. Ojuna havde da også hørt fra sin mor, at hendes far havde været en kraftfuld shaman og duha. Selv havde Ojuna ikke mødt morfaderen, ej heller havde hun hørt særlig meget om ham, eftersom hendes mor var blevet bortadopteret som seksårig og derfor kun huskede ham ganske svagt. 
Shamankaldet havde først frustreret Ojuna, der som moderne kvinde, opvokset og universitetsuddannet i Ulaanbaatar og nu på syvende år gift og bosat i Tyskland, ikke kunne se sig selv som shaman. Alligevel var hendes nysgerrighed blevet vakt, og hun begyndte at opsøge flere shamaner, der alle med overbevisning sagde, at hun skulle være shaman. At flere shamaner også gav meget præcise beskrivelser af hendes morfar, hvis sandhedsværdi Ojunas mor bekræftede, overbeviste hende om, at hun måske alligevel var den udvalgte.

Første gang, jeg hører om Ojuna, er i tajgaen, hvor min adoptivmor Aichurek fortæller mig, at en slægtning er ankommet til steppeområdet Hogrog, en dags rejse fra tajgaen. Som vi sidder i Aichureks tipi, fortæller hun med klar røst: „Ojuna er kommet hertil for at blive shaman. Hun er af shamanen Nazyns slægt, ham, der lavede vores eren. Hun er hans barnebarn, så hun bliver en stor shaman." Min adoptivfar Gosta sidder koncentreret og ruller en cigaret af avispapir, tænder den, inhalerer og puster røgen ud, så hans ansigt ligger sløret af røg. „I morgen kan vi tage til Hogrog og møde Ojuna," siger han henvendt til mig.

Næste dag rider vi til Hogrog. Efter otte timers uafbrudt ridt når vi frem til Hogrog - darhadnomadernes hjemland. Vi stopper ved en lejr med tre små træhytter og en ger (mongolsk filttelt) omkranset af et træhegn. Her bor Ojuna hos nogle af sin mors slægtninge.

Jeg går med Gosta ind i geren og sætter mig ved siden af ham i den venstre side, som er reserveret til gæster. Her møder jeg Ojuna for første gang. En høj velklædt mongolsk udseende kvinde med korthårsfrisure, der står i skarp kontrast til de lokale kvinder, hvoraf de fleste er lave af højde, har langt hår og er klædt i den traditionelle mongolske klædedragt (deel). Ojunas shamanlærer sidder i gerens nordlige hjørne og ryger en cigaret. Han er meget velklædt, bærer en ny beigefarvet traditionel mongolsk klædedragt, og om livet har han et pompøst bælte med et stort bæltespænde af sølv, som minder om dem, de mongolske brydere ofte bærer. Han hilser venligt på mig. Ojuna byder os på mælkete, og de spørger, hvem jeg er. Jeg forklarer, at jeg gerne vil følge Ojunas arbejde med at blive shaman. Shamanlæreren nikker, og Ojuna svarer højt ja og virker glad for mit selskab. Gosta og shamanlæreren går ud af geren, og Ojuna betror mig sin frustration over sin shamanlærer. „Han forklarer mig ingenting. Hvordan skal jeg nogensinde lære det, når han ikke vil forklare mig det, " siger hun frustreret.

Hele bagenden af geren er dekoreret med overdådige shamanistiske genstande. I den venstre side af geren hænger Ojunas shamanlærers tromme, der har en karakteristisk trekantet form og er betrukket med bjørneskind. Ved siden af hænger hans shamandragt, der er dekoreret med en overflod af metalbjælder i alskens former og pels fra over femten forskellige vilde dyr. Ydermere er der ophængt et væld af erenamuletter bestående af ravnehoveder, skind fra utallige dyr, silkeklæder 
etc. I den højre side af geren hænger Ojunas nylavede shamandragt, tromme og eren, der også er smukt og kunstnerisk udformet og langtfra ligner de slidte og mere simple shamandragter og erenamuletter, jeg tidligere har set i tajgaen. „Vi har brugt flere uger på at lave det [shamandragt, tromme og eren]. Min lærer siger, at det skal laves på en helt bestemt måde. Det er vigtigt, at der er pels fra bestemte dyr, " forklarer Ojuna.

Næste dag skal Ojuna forsøge at hidkalde sin morfaders eren. Sammen med sin lærer vil hun for første gang afholde et ritual og tromme iklædt shamandragten. Målet er at hidkalde morfaderens ånder, som er det første skridt på vejen til at blive shaman. Ritualet er et stort tilløbsstykke. Nære og fjerne slægtninge samt lokale fra omegnen har arrangeret biler, så de kan deltage. Ved middagstid kører Ojuna med sin shamanlærer, mig og seksten slægtninge, hvoraf flere er så berusede, at de må bæres ind i bilen, til det bjerg, hvor ritualet skal afholdes.

Da vi ankommer til bjerget, bærer to af Ojunas onkler tre berusede fætre ud af bilen og smider dem i græsset. De er bedøvede af beruselse og opdager intet. Ojunas mor sætter sig i græsset og åbner en flaske vodka. Tre ældre mænd sætter sig ned ved siden af hende, og hun rækker et fyldt glas frem mod den første. Ojuna sender moderen et vredt blik og siger: „I skal ikke drikke vodka nu. “ Moderen råber op og skælder ud, sender Ojuna et trodsigt blik og fortsætter med at dele vodka ud. Ojuna siger irriteret henvendt til mig: „Jeg forstår ikke de her mennesker. De tænker kun på at drikke, og min shamanlærer har endnu ikke forklaret mig, hvad det her ritual går ud på.“

Shamanlæreren er travlt optaget af at anrette et fad med offergaver. Sirligt placerer han et fårebrystben på fadet, så slik og til sidst tobak. Han gør tegn til, at Ojuna skal tænde et bål. Hun går straks i gang med at tænde bålet. Da det brænder godt, rækker han hende en kop med mælk og gør tegn til, at hun skal ofre. Koncentreret dypper hun en ske i mælken og spreder den i alle fire verdenshjørner. Shamanlæreren kommer hen til Ojuna bærende på shamandragten og hjælper hende med at iklæde sig den. Jeg hører et par gamle duhamænd hviske i baggrunden. De siger: „Hvordan skal ånderne nogensinde kunne ankomme om dagen? - Og så med den shamandragt!“

Shamanlæreren hæver stemmen i irritation og siger, at nu skal ritualet begynde, og beder folk samle sig i kreds omkring Ojuna. Kvinder og mænd sætter sig tilfældigt blandt hinanden. Min adoptivfar Gosta råber højt med skinger beruset stemme: „Det er helt forkert, kvinder skal sidde derovre og mænd her!“ Shamanlæreren afbryder irriteret og siger: „Jeg ved, hvordan det skal gøres.“ Ojunas storebror kigger vredt på Gosta, hiver fat i ham og trækker ham væk med ordene: „Du ødelægger det hele.“ Den gamle svarer: „Rolig, rolig, Ojuna skal nok blive en kraftfuld shaman. Kraftfuld, kraftfuld som shamanen Nazyn.“ 
Da ritualet skal begynde, er Ojuna, hendes shamanlærer, en yngre kusine og jeg de eneste, der ikke er mærkbart berusede. Ojunas shamanlærer rækker hende trommen, og hun begynder at tromme monotont. For en stund er folk fokuserede på Ojuna. De hvisker om, hvorvidt små ændringer i trommerytmen er et udtryk for erens ankomst. Folk venter på, at Ojuna skal begynde at synge - et tegn på erens ankomst, men da der efter ca. tyve minutter intet er sket, begynder to gamle mænd at råbe højlydt op om, at hendes shamandragt er lavet helt forkert. „Der skal være en trehovedet slange“ og „,der må ikke være zobelskind“, råber en gammel mand til shamanlæreren, der vredt svarer: „Jeg ved, hvordan det skal laves.“ „Hun har betalt ham [læreren] to millioner tögrögs“, „han er bare en markedsshaman“, „han kender intet til vores traditioner (yos)“", hviskes der. Efter ca. en time opgiver Ojuna og kommer bagefter opgivende over til mig og siger: „Jeg mærkede ikke noget, og jeg ved heller ikke, hvad jeg skal mærke.“ Shamanlæreren hjælper Ojuna af tøjet og siger henvendt til hende: „Jeg mærkede dine eren. De er meget vilde, de ankommer snart, måske næste gang.“

Et par dage efter afholder Ojuna igen et ritual, som også mislykkes. I lejren taler folk om, at det er Ojunas lærers skyld. Han er ikke duhashaman og kender ikke traditionerne. Og mest af alt har han ikke lavet Ojunas shamanudstyr efter reglerne i hendes slægt, hvilket kan, som en duha forklarer, ikke blot forhindre Ojunas initiering, men også føre til, at hun bliver gal eller dør. Tingene er alt for pompøse og kostbare, hvilket ikke er i overensstemmelse med reglerne og giver dem karakter af „dårlige ting“, som en informant forklarer:

Shamaner i Ojunas slægt anvendte ikke gyldent zobelskind, det gjorde de med sikkerhed ikke. Eren bryder sig ikke om sådan nogle kostbare ting. Kostbare ting bærer 'dårlige ting' i sig, fordi folk strides om at få dem. I gamle dage brugte man ikke kostbare ting. De lavede ganske enkelt shamandragten af hjorteskind og den slags. De afdøde fra oven fortæller om de ting, en eren har brug for. Alting skal laves i overensstemmelse med fortidige shamaner i slægten. Det er min holdning, at redskaber til en shaman i shamanen Nazyns slægt bør indeholde en trehovedet sort slange, hjorte- og rensdyrskind. Hendes hovedprydelse er også lavet helt forkert, fjerene er o.k., men de er placeret forkert [...]. Når shamandragten ikke er lavet efter reglerne (yos), kan de [eren] ikke genkende deres klan, og de bliver i stedet vrede.

Ojunas shamandragt var således ,en dårlig ting“ eller en samling af ,dårlige ting“, fordi den ikke var lavet i overensstemmelse med de regler, der kendetegnede hendes morfars eren. Tilstedeværelsen af de „dårlige ting“ materialiserede Ojunas og hendes shamanlærers mangel på viden om morfaderens erens særlige egenart og iboende regler, et „fravær af viden“, der på én gang udfordrede Ojunas shamanlærers autoritet og igangsatte Ojunas søgen efter viden om hendes erens sande natur. 


\section{Multiple verdener}

En ældre duhakvinde sagde til Ojuna, at hun først ville blive shaman, hvis hun besøgte sin morfars eren ved det offertræ, hvor slægten havde placeret den efter hans død. Dette blev hun dog frarådet af to ældre duhamænd, der fortalte hende, at træet var vildsindet (dogshin), ${ }^{5}$ fordi slægten i årtier ikke havde besøgt det. I stedet rådede de Ojuna til at rejse til tajgaen for at ofre til en erenamulet, som hendes morfar havde lavet til sin brors slægt, en eren, der i dag er placeret i shamanen Ariunas telt.

De fleste dage hænger Ariunas eren gemt væk i en brun stofsæk placeret i teltets nordlige område. Men den dag, hvor Ojuna og jeg besøger Ariuna, hænger den frit fremme. Det er den første månedag i sommerhalvåret, en særlig lykkebringende dag, hvor duhaerne ofrer til deres erenamuletter. Ariunas eren er et tungt bundt af flere hundrede hvide og blå stofstrimler. Fra midten af bundtet trækker Ariunas søster Aichurek en lædersnor frem, hvorpå der er fæstnet en ørneklo, og fortæller:

Vores fars storebror, shamanen Nazyn, lavede denne eren for over 60 år siden. Det var ham, der fæstnede ørnekloen og de første stofstrimler og gjorde den levende. Dens kraft er ørnens, Nazyns og ja, jeg ved ikke. Den består også af noget mere, som kun shamaner kender til. Han lavede den til alle os børn for at se efter os, passe på os. Nu beskytter den hele vores slægt. Han var en meget god, hvid og stærk shaman.

Duhaernes erenamuletter er på mange måder lig nabofolket darhads „ongod“, beskrevet af Pedersen $(2007,2011)$. Begge er amuletter, der udgør „en kompleks sammensmeltning af hændelser, sociale relationer og materielle substanser, der kontinuerligt absorberer nye hændelser, sociale relationer og materielle substanser [...], der defineres af den første hændelse, som ånden [ongod] blev skabt af“ (Pedersen 2007:156). Dog adskiller duhaernes erenamuletter sig fra darhadfolkets ongodamuletter, ved at de første primært har oprindelse i ikke-menneskelige kræfter og ånder, mens de sidste har oprindelse i menneskeånder (Vainshtein 1978; Humphrey 1996). Eksempelvis udgøres Arinuas eren både af ørnen og shamanen Nazyns kraft og/eller ånd samt flere unavngivne kræfter og/eller ånder af ikkemenneskelig oprindelse.

Duhaernes shamanistiske ontologi synes at udspilles gennem deres erenamuletter, hvor hver eren har sin særlige natur, som definerer og former arten af - og foreskriver særlige regler for interaktion med - ting i verden for medlemmerne af den enkelte shamanslægt. Hver erenamulets fysiske form (farven på stofstrimler, dele fra særlige dyrearter) er unik og materialiserer den enkelte erens unikke natur, som huskes og reproduceres gennem de særlige regler og offerhandlinger, der er knyttet til den. Som en ældre kvindelig informant forklarede: 
I vores slægt placerer vi ikke kød fra sorthårede dyr i nærheden af vores eren. Vores eren væmmes ved kød fra disse dyr. Bjørne- og vildsvinekød [kød fra sorthårede dyr] står i kontrast til vores eren, men elgkød er i orden. Sådan er det i vores slægt, men i andre slægter er det anderledes. Alle slægter er forskellige, fordi de har forskellige eren. Hver slægt har sine regler.

Duhaernes erenamuletter synes at udgøre et domæne af ,,animistiske analoge identifikationer", hvor hver eren udgør sin særlige verden, som er analog med dens iboende natur (dyre- og andre ikke-menneskelige ånder og kræfter), historie (fortidige og nutidige slægters handlinger) og regler, som igen er analog med den nulevende slægts skæbne og verden. En eren med oprindelse i en ørneånd vil eksempelvis betragte ting lavet af sorthårede dyr som frastødende, og fæstner shamannovicen sådanne ting til sin shamandragt, vil det ophidse novicens eren og potentielt medføre hendes sindssygdom eller død.

Duhaerne synes således at betragte det menneskelige samfund som bestående af ,gensidigt uafhængige domæner" materialiseret i familiers og slægtsgruppers erenamuletter. Sådanne domæner repræsenterer ikke blot sociale grupperinger og sociale regler, men synes også at udgøre multiple verdener, hvis særegne natur har sine særlige regler og materialiserer sin unikke version af „naturloven“. Erenamuletterne udgør et slags levende kort over de multiple verdener, der kommer til syne, når duhaerne anvender deres fælles ,naturlov“ til at forstå deres egen egenart. Dette betyder, at verdens beskaffenhed, set fra duhaernes perspektiv, er forskellig fra slægt til slægt, da den formes af egenarten af den enkelte slægts eren. Kun når shamannovicens shamandragt er konstrueret således, at den imiterer hendes erens særlige natur, vil hendes eren genkende hende, slå sig ned i hendes shamandragt og gøre hende til shaman. Ligeledes skal også slægtens øvrige medlemmer ideelt interagere med ting på en måde, der imiterer deres erens særlige natur og verden for at undgå sygdom og ulykke. Duhaernes udfordring er, at de ofte kun har begrænset viden om deres erenamuletter og dermed om tingenes og verdens sande beskaffenhed.

\section{Slægt eller fjende?}

Duhaerne kan aldrig vide sig helt sikre på tingenes og verdens beskaffenhed, da de ofte mangler viden om deres erens sande natur. Eksempelvis var beskaffenheden af Ojunas morfars eren uklar, da hverken Ojuna eller hendes slægtninge helt vidste, hvori den bestod. Den uklarhed blev tydelig for Ojuna, hver gang duhaerne påpegede tilstedeværelsen af ,dårlige ting“ $\mathrm{i}$ hendes shamandragt.

Først når Ojunas morfars ånder genkendte hende som slægt, ville hun blive shaman, en genkendelse, der afhang af, at hendes shamandragt stemte overens 
med morfaderens erens særegne natur. Ojuna fulgte de råd, duhaerne gav hende, om at udskifte ting i sin shamandragt $i$ håbet om at finde frem til de rette ting. Flere gange kom hun tæt på, og morfaderens eren accepterede hende delvist, men kun delvist, fordi tingene stadig ikke passede helt.

Ojuna manglede viden om sin morfars eren, da hun aldrig havde set den, ej heller kendte til dens særlige beskaffenhed. En ældre mand i tajgaen rådede hende til at etablere kontakt til sin morfars eren ved at ofre til den på sikker afstand. Det ville være for farligt at nærme sig selve det offertræ, hvor den var placeret, da stedet og morfaderens eren var vildsindet. Sammen med flere familiemedlemmer tog Ojuna til et bjerg tæt på morfaderens offertræ. Her fæstnede hun hvide stofstrimler til et cedertræ, placerede slik, kager og ost på et offerfad, ofrede mælk og vodka og lagde tre tændte cigaretter oven på offerfadet. Ofringen blev ifølge hendes fætter godtaget, da cigaretterne ikke gik ud, men brændte helt ned. Formålet med ritualet var ifølge Ojuna at gøre morfaderens eren venligsindet og få den til at genkende hende som slægt. Viveiros de Castros (1998) teori om indiansk perspektivisme kan belyse, hvordan duhaerne betragter deres erens perspektiv på shamannovicen som afhængigt af offerhandlingernes og shamanudstyrets beskaffenhed.

Indiansk perspektivisme er baseret på princippet om at ,synsvinklen skaber subjektet" (op.cit.466), en forestilling i animistiske ontologier om, at mennesker og ikke-mennesker alle har subjektivitet, men ,opfatter virkeligheden fra forskellige synsvinkler“" (op.cit.469). Dette indebærer ideen om, ,at dyr og ånder betragter sig selv som mennesker (rovdyr) og ser mennesker som ikke-mennesker (byttedyr) på samme vis, som mennesker ser sig selv som mennesker (rovdyr), ånder som ånder og dyr som dyr (byttedyr)“(op.cit.470). ,Alle væsener ser [,,repræsenterer"] verden på samme vis. Hvad der er foranderligt, er den verden, de ser“" (op.cit.477). Ifølge Viveiros de Castro er synsvinklen lokaliseret i kroppen, og skift i klædedragt kan føre til symmetriske ombytninger mellem mennesker og ikke-mennesker, subjekt og objekt, rovdyrs og byttedyrs perspektiver (op.cit.478). Noget lignende synes at gøre sig gældende blandt duhaerne, hvor shamanen potentielt kan opnå åndernes perspektiv, når hun iklæder sig shamandragten. Dette forklarede shamanen Gompo med ordene: „Når jeg iklæder mig shamandragten, er det, som om mit eget sind forsvinder. Jeg begynder i stedet at se med min erens øjne." Ligeledes afhænger åndernes syn på shamannovicen som slægtsmedlem eller udefrakommende af, hvorvidt novicens offergaver og shamanudstyr stemmer overens med slægtens eren. Uoverensstemmelsen mellem Ojunas shamanudstyr og eren betød, at morfaderen ikke genkendte hende som et medlem af slægten og en potentielt ny shaman. Faren var tilmed, at morfaderens eren ville se hende som en udefrakommende, hvilket potentielt kunne ophidse ånderne og få fatale følger for Ojuna. 
En eren kan forstås som et slags troldspejl. Den spejler ikke blot en objektiv verden, men er et spejl på, hvordan verden ser ud, når den ses igennem de myriader af menneskelige og ikke-menneskelige kræfter, den udgøres af. Hvordan verden ser ud igennem dette troldspejl, er ikke fast, men foranderligt, eftersom slægtens handlinger og offergaver kontinuerligt indkapsles i spejlet og således i spejlbilledet. Verdens beskaffenhed er for duhaerne et flydende felt, da tingens karakter formes af erens potentielt variable indhold, en foranderlighed, duhaerne forsøger at kontrollere gennem ofringer. Ifølge duhaerne skal man ofre til sin eren for at forny (shinechlyeh) den. Med fornyelse menes ikke forandring, men reproduktion af erens oprindelige natur. Ofringer skal ideelt set passe sammen med den enkelte eren, hvorfor fornyelse af kraft er imitation af erens iboende natur.

Grunden til, at Ojuna ikke opnåede åndernes perspektiv, da hun iklædte sig shamandragten, var, at den indeholdt ,dårlige ting“, som stod i kontrast til hendes morfars eren. Blandt duhaerne er ting ikke dårlige i sig selv; snarere er der tale om, at tingenes beskaffenhed er forankret $i$ en relation. Ojunas shamandragt var dårlig, fordi den indeholdt zobelskind, som på én gang materialiserer zobeldyrets særlige egenart som dyr og rigdom og stridigheder mellem mennesker. Dette stod i modsætning til slægtens erenamuletter, der ifølge en informant altid var blevet lavet af ,fredelige og hurtige dyr såsom hjorte og hjorteskind“, som materialiserer hjortens særlige natur og reciprocitet og venskab mellem mennesker. ${ }^{6}$ Hvorvidt en ting passer sammen med en given eren, afgøres ikke alene af dens oprindelse i et særligt dyr eller en særlig ikke-menneskelig kraft, men også af de myriader af fortidige menneskelige hændelser og relationer, som også former den enkelte erens særlige natur. Dette blev synligt for mig, da Ojuna i forsøget på at hidkalde sin morfars eren og blive shaman fulgte duhaernes råd om at fyre sin mongolske læremester og i stedet tage en lokal duhashaman, shamanen Ganzorig, som mentor.

Shamanen Ganzorig sagde til Ojuna, at hun først skulle hidkalde ånderne med shamanens såkaldte lille hest, jødeharpen. Først når hun mestrede denne, kunne hun begynde at tilkalde ånderne med shamanens store hest, trommen. Ganzorig lavede en jødeharpe til Ojuna i overensstemmelse med forskrifterne i Ojunas slægt. Alligevel ankom ånderne ikke, da Ojuna spillede på jødeharpen. En lokal spåkone fortalte Ojuna, at det skyldtes, at hendes morfar og shamanen Ganzorigs farfar havde ligget i strid, en kamp mellem historiske shamaner, der betød, at en jødeharpe konstrueret af Ganzorig for Ojuna var en „dårlig ting“. Den stod i direkte kontrast til shamaner i hendes slægt, som en ældre kvinde forklarede:

Hendes eren bliver frastødt af den jødeharpe, fordi de var i strid med hinanden i fortiden. De bliver frastødt, fordi de står i kontrast til hinanden, fordi de har oprindelse i forskellige ezen [herskerånder], forskellige offersteder, forskellige slags kraft og meget andet. 
Således er bestemte ting dårlige for bestemte slægter, hvis tingen står i kontrast til deres erens særlige natur og verden, en verden, der forbinder fortid, nutid og fremtid $i$ en analogisk relation, der udgør den verden, den enkelte shaman og det enkelte medlem af slægten skal leve i overensstemmelse med for at undgå ulykker. Mennesker skal ideelt handle i verden og interagere med ting på en måde, der imiterer deres erens iboende regler og natur, for kun herved kan de bibeholde deres position som medlemmer af slægten og undgå, at deres eren ser dem som ikke-slægtsmedlemmer og potentielle byttedyr.

\section{Fatale amuletter}

At omgangen med erenamuletter kan være fatal, hvis man ikke interagerer med dem efter deres iboende regler, blev tydeligt for Ojuna under hendes ophold i tajgaen. I perioden 2009-2010 havde der fundet en række uforklarlige dødsfald sted blandt Ojunas familie i tajgaen. Blandt duhaerne var der enighed om, at dødsfaldene ikke var tilfældige, eftersom de alle var sket om foråret. De døde var alle af samme shamanslægt og knyttet til den samme eren. I lejren opstod der flere rygter om den sande årsag bag dødsfaldene. Fælles for dem var, at de omhandlede ukorrekt omgang med slægtens fælles eren. Et rygte gik på, at ulykkerne stammede fra en offergave af råt kød, som en beslægtet shaman fra Ulaanbataar - Ojunas moster - havde ofret til familiens eren, en offergave, der ifølge duhaerne stod i kontrast til og derfor ikke passede til deres erens egenart. Dette modsætningsforhold havde transformeret deres erens væsen fra venligsindet til vildsindet, hvorpå den var begyndt at sprede død og ulykke blandt slægten. I tajgaen fortalte en ældre slægtning:

For to år siden kom denne kvinde, shamanen Mend, en af Nazyns døtre, til tajgaen. Hun sagde, at hun var shaman, og ofrede råt kød og vodka til vores eren. Det så virkelig respektløst ud. Men vi sagde ikke noget, for hun var jo shaman. Bagefter rejste hun til shamanen Nazyns offertræ ved floden Tengis for at ofre til hans eren, som er placeret der. Kort tid efter døde hun, og dødsfaldene startede. Min far ofrede aldrig kød til vores eren. 'Kød er en dårlig ting for vores eren,' sagde han. Så kød tillod han end ikke at komme nær vores eren. Nogle familier kan måske ofre kød til deres eren, uden at der sker noget, men ikke vores familie.

Offergaver skal således ideelt stemme overens med den enkelte erens iboende natur, eftersom offergaver, der går på tværs af denne natur, vil udgøre et brud på slægtens regler, hvilket kan føre til en fatal ændring af dens sindelag og dermed nedkalde død og ødelæggelse over slægten. 


\section{En verden af rygter}

Da Ojuna påbegyndte sin rejse hen mod at blive shaman, havde hun kun begrænset viden om duhaernes shamanistiske tradition. Efterhånden som hun gennemgik flere og flere ritualer og lyttede til flere og flere rygter og historier om hendes morfars eren, fik hun ny indsigt i de overordnede værdier, der udgør duhaernes „naturlov“, og ny viden om sin erens særlige egenart og regler. Denne viden konfronterende samtidig Ojuna med ny uvidenhed, da hver betydning åbnede nye uklarheder. Ojunas eren brød sig ikke om zobelskind, men foretrak hjorte- og rensdyrskind. Den stemte ikke overens med shamanlærere af mongolsk herkomst, men foretrak duhaer - men ikke enhver duha. Den brød sig ikke om rødt råt kød, men foretrak mælk, tobak og vodka.

Som vi har set, udgør duhaernes erenamuletter et slags levende kort over duhaernes verdener, hvor de „dårlige ting“ synliggør de overordnede principper i duhaernes „,naturlov“ og det særegne udtryk, den antager i den enkelte shamanslægt. Tilstedeværelsen af en „dårlig ting“" materialiserer et brud på slægtens regler og synliggør et „fravær af viden“ om slægtens verden, der ofte igangsætter individets/gruppens søgen efter viden om denne verdens særlige egenart og iboende regler. Det er min tese, at slægternes verdener kontinuerligt skabes og genskabes i en dialektik mellem individets/gruppens erfaring med ,dårlige ting“ og viden om erenamuletter samt „,fravær af viden“ og opnåelse af viden om amuletterne. Det er denne dialektik, der bidrager til en kontinuerlig etablering og reetablering af viden om erenamuletternes verdener og naturer, hvorigennem principperne i duhaernes ,naturlov“ synliggøres og forhandles. Hver gang Ojuna fik kendskab til en af de regler, der karakteriserede hendes eren, blev hun samtidig konfronteret med, at der var en anden regel, hun ikke kendte til. Dette drev hende videre i sin søgen, som gang på gang gav hende nye indsigter, der indeholdt nye lag af uvidenhed. Da hun fik at vide, at reglerne i hendes slægt foreskrev, at hun fik en duhask shamanlærer, fyrede hun sin mongolske lærer, der forsmået rejste sin vej. Efter at flere duhaer havde fortalt hende, at shamanen Ganzorig var den stærkeste shaman i tajgaen, tog hun ham som lærer. Da det kun delvist lykkedes for ham at hidkalde hendes eren, opsøgte hun en lokal spåkone. Denne sagde, at Ojuna under ingen omstændigheder måtte beholde Ganzorig som shamanlærer, da deres eren historisk havde bekæmpet hinanden, men hvordan og hvornår afslørede hun ikke.

Hver gang Ojunas forsøg på at blive shaman mislykkedes, opstod der nye rygter om de skjulte årsager bag erens manglende ankomst, rygter, der omhandlede relationen mellem fortidige og nutidige hændelser. Disse rygter berettede ofte om nutidige skæbners oprindelse i historiske brud på reglerne. Eksempelvis gik der et rygte om, at Ganzorigs bedstefar havde forbrudt sig mod slægtens regler 
ved at lave sort magi, hvorfor slægten siden havde været ramt af alskens ulykker. Et andet rygte gik på, at Ojunas morfars eren i dag var vildsindet, fordi slægten, presset af det socialistiske styres undertrykkelse af traditionen, havde glemt den. Og da slægten efter den socialistiske stats sammenbrud endelig fik en shaman - shamanen Mend - gjorde hun slægtens eren endnu vildere, da hun brugte den til at tjene penge.

\section{Konklusion}

Som vi har set, er erens kræfter ofte af flertydig karakter, og tilsvarende er verdens beskaffenhed omgærdet af flertydighed, en flertydighed, der også er karakteristisk for rygter. Således synes det, som om verdens flertydighed bedst begribes igennem en form, nemlig rygtets form, der som verden er flertydig. Hvorvidt et rygte anerkendes som potentielt sandt, afhænger af, hvorvidt det afspejler de overordnede principper i „naturloven“, og af folks eksisterende viden om deres erenamuletter.

Det duhaske fænomen ,den dårlige ting“ kan således alene forstås ved at tage deres begreb om ,alle slægter er forskellige, fordi de har forskellige eren“ alvorligt. Dette udsagn afspejler duhaernes „naturlov“, som indebærer ideen om, at hver shamanslægt bebor sin erens særegne verden. Duhaernes verden består således af multiple verdener, hvis beskaffenhed er af labil og uafgjort karakter, da de kontinuerligt konstrueres og rekonstrueres i en dialektik mellem viden og „fravær af viden“ om erenamuletter, en dialektik, der drives fremad af opkomsten af sygdom og ulykke eller af åndernes manglende ankomst, som indikerer tilstedeværelsen af en „dårlig ting“ og materialiserer et „fravær af viden“ om slægtens eren, der udfordrer slægtens eksisterende viden om - og iværksætter en søgen efter og rygter om - den enkelte erens sande natur.

\section{Noter}

1. Blandt duhaerne refererer begrebet „eren“ både til slægtens særegne ånder (eren) og de konkrete amuletter (eren), de bebor.

2, I artiklen bruger jeg termen ontologi i dets umiddelbare filosofiske betydning, altså læren om væren og verdens beskaffenhed.

3. Hver slægt udgør sin særegne verden, da tings beskaffenhed (lige fra en kop, et zobelskind til et træ) i verden betragtes som forskellig fra slægt til slægt, da den formes af den enkelte slægts eren.

4. Jeg betegner den styreform, der gjorde sig gældende i Den Mongolske Folkerepublik og Sovjetunionen, som socialistisk og ikke kommunistisk, da det er sådan, mongolerne og duhaerne selv betegnede og betegner den daværende styreform. 
5. Duhabegrebet dogshin (vildsindet) bruges til at beskrive dyr, ånder og steders temperament. På samme vis som en hest kan være vildsindet, dvs. uregerlig, uberegnelig og potentielt farlig, kan ånder og steder være vildsindede.

6. Ovenstående er knyttet til duhaernes jagttraditioner, hvor reglen er, at den jæger, der skyder en zobel, har eneret til den, mens den jæger, der skyder en hjort, er forpligtet til at dele kødet med resten af lejren.

Søgeord: shamanisme, ting, ontologi, viden, fravær af viden, rygter

\section{Litteratur}

Buyandelgerin, Manduhai

2007 Dealing with Uncertainty: Shamans, Marginal Capitalism and the Remaking of History. American Ethnologist 34(1):127-47.

Charleux, Isabelle

2010 From Ongon to Icon. In: I. Charleux, G. Delaplace, R. Hamayon \& S. Pearce (eds.): Representing Power in Ancient Inner Asia: Legitimacy, Transmission and the Sacred. Pp. 209-61. Bellingham: Western Washington University.

Empson, Rebecca

2007 Separating and Containing People and Things in Mongolia. In: A. Henare, M. Holbraad \& S. Wastell (eds.): Thinking Through Things. Theorising Artefacts Ethnographically. Pp. 113-40. London: Routledge.

2011 Harnessing Fortune: Personhood, Memory, and Place in Mongolia. Oxford: Oxford University Press.

Henare, Amiria, Martin Holbraad \& Sari Wastell

2007 Introduction. In: A. Henare, M. Holbraad \& S. Wastell (eds.): Thinking Through Things. Theorising Artefacts Ethnographically. Pp. 1-31. London: Routledge.

Humphrey, Caroline

1971 Some Ideas of Saussure Applied to Buryat Magical Drawings. In: E. Ardener (ed.): Social Anthropology and Language. Pp. 271-90. London: Tavistock Publications.

1996 Shamans and Elders: Experience, Knowledge and Power among the Daur Mongols. Oxford: Oxford University Press.

1999 Shamanic Practices and the State in Northern Asia: Views from the Centre and the Periphery. In: N. Thomas \& C. Humphrey (eds.): Shamanism, History and the State. Pp. 191-228. Michigan: The University of Michigan Press.

2002 Rituals of Death as a Context for Understanding Personal Property in Socialist Mongolia. Royal Anthropological Institute 8:65-87.

2007 Inside and Outside the Mirror: Mongolian Shamans: Mirrors as Instruments of Perspectivism. Inner Asia 9(2):141-53.

Højer, Lars

2009

Absent Powers: Magic and Loss in Post-Socialist Mongolia.

Journal of the Royal Anthropological Institute 15:575-91.

Kristensen, Benedikte Møller

2004 The Living Landscape of Knowledge: An Analysis of Shamanism among the Duha Tuvinians of Northern Mongolia. Specialerækken nr. 317. Institut for Antropologi. Københavns Universitet

2007a The Human Perspective. Inner Asia 9(2):275-92. 
Lévi-Strauss, Claude

1963 Totemism. Boston: Beacon Press.

Lindquist, Galina

2011 Ethnic Identity and Religious Competition: Buddhism and Shamanism in Southern Siberia. In: G. Lindquist \& D. Handelman (eds.): Religion, Politics and Globalization: Anthropological Approaches. Pp. 69-90.

New York \& Oxford: Berghahn Books.

Pedersen, Morten Axel

2001 Totemism, Anismism and North Asian Indigenous Ontologies. Journal of the Royal Anthropological Institute 7:411-27.

2007 Talismans of Thought. In: A. Henare, M. Holbraad \& S. Wastell (eds.): Thinking Through Things. Theorising Artefacts Ethnographically. Pp. 141-67.

London: Routledge.

2011 Not Quite Shamans: Spirit Worlds and Political Lives in Northern Mongolia. Ithaca, NY: Cornell University Press.

Purev, Otogony \& Gurbadaryn Purvee

2005 Mongolian Shamanism. Ulaan Bator: Admon.

Shinamura, Ippei

2004 The Movement for Reconstructing Identity through Shamanism: A Case Study of the Aga-Buryats in Mongolia. Inner Asia 6:197-214.

Vainshtein, Sevyan

1978 The Erens in Tuva Shamanism. In: V. Diozegy \& M. Hoppál (eds.): Shamanism in Siberia. Pp. 457-68. Budapest: Akadémiai Kiadó.

Vitebsky, Piers

1995 From Cosmology to Environmentalism: Shamanism as Local Knowledge in a Global Setting. In: R. Fardon (ed.): Counterworks: Managing the Diversity of Knowledge. Pp. 182-202. London \& New York: Routledge.

Viveiros de Castro, Eduardo

$1998 \quad$ Cosmological Deixis and Amerindian Perspectivism.

Journal of the Royal Anthropological Institute 4:469-88.

Wheeler, Alan

2000 Lords of the Mongolian Taiga: An Ethnohistory of the Dukha Reindeer Herders. MA Thesis. Dept. of Central Asian Studies. Indiana University.

Willerslev, Rane

2007 Soul Hunters: Hunting, Animism and Personhood among the Siberian Yukhagirs. Berkeley \& Los Angeles: University of California Press. 